\title{
Professional Development Interest Of Malaysian Math And Science Teachers In The English For Teaching Math And Science (ETeMS) Buddy System
}

\author{
Jayakaran Mukundan, Universiti Putra Malaysia (UPM), Malaysia \\ Reza Hajimohammadi, Universiti Putra Malaysia (UPM), Malaysia \\ Vahid Nimehchisalem, Universiti Putra Malaysia (UPM), Malaysia
}

\begin{abstract}
Professional development activities are needed to enhance teachers' performance. Likewise, in the Malaysian educational system, teachers are encouraged to go through such activities each year. There is need to study teachers' views on these activities in order to design more appropriate professional development programs. The present study sought to investigate a group of Malaysian Math and Science teachers' interest in professional development. For this purpose, a survey study was conducted by administrating a questionnaire to a group of school teachers $(n=300)$ in the State of Melaka. Analysis of the data revealed that female teachers were more interested in participating in professional development activities. Furthermore, Math teachers reportedly indicated higher interest in these activities than Science teachers. Additionally, as the results showed, less experienced teachers were more eager to take part in professional development programs than those with higher teaching experience. Finally, it was found that providing administrative support encouraged teachers' participation in professional development activities. The results can shed light on the steps that the administrators need to take in order to improve the quality of the professional development programs of this sort.
\end{abstract}

Keywords: Professional development interest; Teaching Math and Science in English

\section{INTRODUCTION}

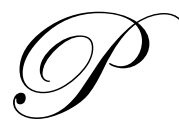

rofessional development is regarded as engaging teachers in activities that enhance their performance which may result in their learners' achievement (Kohl, 2005). Such activities take place under the approval of the school in which they are employed. There is research evidence that teachers' professional development can improve their performance in the classroom and result in students' better learning (Pritchard \& Marshall, 1994). Ladson-Billings and Gomez (2001) regard professional development activities "as the linchpin of school reform aimed at raising academic performance. No amount of standards, benchmarks, and highstakes testing can bring about school improvement without attention to teacher quality" (p.680).

There have been several studies on foreign (mainly Spanish) language teachers' professional development activities. These studies, nevertheless, mainly seek to describe professional development programs (LeLoup \& Schmidt-Rinehart, 2003; Lozano, Sung, Padilla, \& Silva, 2002; Peyton, 1997; Schmidt-Rinehart, 1997; Terdy, 1993). Other studies, such as Pelavin Associates (1994), Grittner and Knop (1975) and Thomson (1985), present empirical findings. However, they either have a small sample size or lack the expected quality of empirical research (Kohl, 2005).

In some developing countries where knowledge of science and technology is widely available in English, curriculum developers in educational ministries plan to support the students by teaching some or all the subjects in 
English. Such immersion programs help students both learn the subjects in different content areas and develop their English language skills. However, these programs necessitate certain professional development activities to help the teachers adjust themselves with the new materials or teaching methods.

Malaysia has not been an exception in this respect. The Ministry of Education presented a new subject in 2003 to develop Malaysian students' English language skills (Kementerian Pendidikan Malaysia, 2003). A subsequent measure was the introduction of the policy of English for the Teaching of Mathematics and Science (ETeMS). Out of the urgent need to empower the Malaysian school students as the future researchers of the country and to globalize them, the idea was implemented too quickly. However, such policies have been known to effect challenges, like availability of teachers (Kaplan \& Baldauf, 1997).

The Ministry of Education had some plans to tackle some of the expected problems. As the agents of change in schools, the Math and Science Teachers (MSTs) would encounter difficulties in upgrading the essential English language skills. For this purpose, the English Language Teaching Center (ELTC) was established. It would provide in-service English language training for the MSTs (Kementerian Pendidikan Malaysia, 2003). The ELTC set up an English language enhancement program that was referred to as English for the Teaching of Mathematics and Science (ETeMS). The focus of ETeMS was on enhancing the teachers' ability in using English as the medium of instruction in their classrooms. In conjunction with this training, a Buddy System would also be implemented to smooth the progress of the teaching of mathematics and sciences in English (Yeow, 2003). The system involved the teachers in cooperative support as 'critical friends' in every school. The 'critical friend' is a teacher of English language, mathematics or science who designs the test and assists to solve the problems related to the use of English. All language skills were emphasized in the program but the focus was mainly on developing the speaking skills and the related grammar knowledge. The program specified 240 hours for instructing the teachers. A cascade strategy was followed in which some central trainers would be trained to prepare some other key trainers who would subsequently train other teachers (Chan \& Tan, 2006).

The accomplishment of ETeMS increased many concerns and discussions among classroom practitioners. Among classroom practitioners there exist some challenges for the achievement of ETeMS. The MSTs have mixed viewpoints towards teaching Mathematics and Science in English. Some of them are sanguine and pleasured but there are in addition some who are indifferent and negative about it. Studying the effective view of the MSTs could provide researchers with fundamental understanding of the context. The creative tension that comes with the changes will lead to new ways of doing things. As such, it is necessary to find out the impact of ETeMS on the existing beliefs of the teachers. There exist several accounts of the achievement and failure of ETeMS, while there are few studies which examine the teachers' professional development interests in Buddy System in Malaysia.

Investigating the professional development experiences and interests in North Carolina of foreign language teachers and ESL, Kohl (2005) made a sample survey. To pursue professional development, she investigated the teachers' professional development and examined the perceived level of administrative support of teachers of English as a foreign and second language. General demographic data including gender, ethnicity, age, educational level, experience, teaching level, and involvement in professional development organization were collected. Kohl's study did not result in any meaningful findings due to lack of enough data. However, reportedly the experienced teachers in her survey were found significantly interested in professional development activities (Kohl, 2005).

In Malaysia, Pandian and Ramiah (2004) studied the MSTs' reactions to ETeMS, the problems they faced and the availability of sufficient support by the educational system. Although they found over $76 \%$ of these teachers perceived the program positively, they expressed a need for more similar professional development programs to improve their English language skills. Interestingly, their findings also indicated that the teachers were prone to fall back to their first language as they found it difficult to explain certain concepts in English. With regard to the support that they received, a large proportion of the respondents (70\%) indicated that they were assisted whenever they required help (Pandian \& Ramiah, 2004, p. 58). 


\section{OBJECTIVES OF THE STUDY}

The first objective of the study is to establish whether there are any differences in the frequency of the respondents' demographics and their perceived level of professional development interest. An additional objective is to study the perceived level of administrative support the MSTs received to pursue professional development activities within the ETeMS buddy system. Furthermore, of interest is to test any dependence of the teachers' interest in professional development on their demography. A final objective is to examine any dependence of the MSTs' interest upon the administrative support that they received.

\section{RESEARCH QUESTIONS AND HYPOTHESES}

The research questions of the study are as follows:

1. Do the teachers indicate any interest in the professional development activities provided for them in the form of the English for teaching Math and Science (ETeMS) buddy system?

2. Are there any significant differences in the frequency of MSTs' gender towards their interest in professional development activities within the ETeMS buddy system?

3. Are there any significant differences in the frequency of MSTs' teaching experience towards their interest in professional development activities within the ETeMS buddy system?

4. Are there any significant differences in the frequency of MSTs' major towards their interest in professional development activities within the ETeMS buddy system?

5. Are there any significant differences in the frequency of MSTs' administrative support towards their interest in professional development activities within the ETeMS buddy system?

To answer the research questions the following null hypotheses were formulated:

$\mathbf{H}_{\text {O1 }}$ : There are no significant differences in the frequency of MSTs' gender towards their reported professional development interests.

$\mathbf{H}_{\mathbf{0} 2}$ : There are no significant differences in the frequency of MSTs' teaching experience towards their reported professional development interests.

$\mathbf{H}_{\mathbf{0 3}}$ : There are no significant differences in the frequency of MSTs' major towards their reported professional development interests.

$\mathbf{H}_{\mathrm{O} 4}$ : There are no significant differences in the frequency of MSTs' administrative support towards their reported professional development interests.

\section{RESEARCH METHODOLOGY}

The purpose of this study is to explore the relationship between EMSTs' interest in professional development activities and their demographics as well as the administrative support they receive in pursuing the professional development activities. To this end, a survey study was conducted. The population, samples, instrument and the data analysis method are discussed in this section.

\section{Population and Sample}

The population of the study was the in-service primary and secondary school Mathematics and Science teachers who had been engaged in English for teaching Math and Science (ETeMS) within the Buddy System. The sample included 300 teachers who were randomly taken from the population list of Mathematics and Science teachers available in the Ministry of Education in Melaka, a province in the south-west of Peninsular Malaysia. Stratified sampling method was employed to ensure an adequate proportion of samples from varying genders, experiences and major.

\section{Instrumentation}

A questionnaire developed by Kohl (2005) entitled the Survey of Professional Development Needs of 
Second Language Teachers (SPDNSL) was adapted for the purpose of this research. Since SDNSLT has focused on the professional development needs of the ESL and foreign language teachers of North Carolina in the US, slight modifications had to be made in a way that the items could be generalized to explore the professional development interest of MSTs in the context of Malaysia.

\section{Data Analysis}

Since the objective of the study was to test the relationship between the Science and Math teachers' interest and their age, experience and major as well as the administrative support that they received, the most appropriate method to analyze the collected data would be Chi-Square. SPSS (Version 18) was used to analyze the data.

\section{RESULTS}

This section deals with analysis and interpretation of data collected with the help of a questionnaire as the instrument of the study. Table 1 presents the descriptive statistics results:

Table 1: Descriptive Statistics Results for All Variables

\begin{tabular}{llcccc}
\hline & & Frequency & Mode & $\%$ & $\begin{array}{c}\text { Ratio of respondents with } \\
\text { low to high levels of interest }\end{array}$ \\
\hline Gender & Male & 84 & $\checkmark$ & 28 & $35 / 65$ \\
Teaching experience & Female & 216 & & 72 & $27 / 73$ \\
& Less & 56 & & 19 & $5 / 95$ \\
\multirow{3}{*}{ Major } & More & 244 & $\checkmark$ & 81 & $16 / 84$ \\
& Math & & & & $12 / 88$ \\
\multirow{4}{*}{ Administrative support } & 146 & $\checkmark$ & 56 & $18 / 82$ \\
& Science & 115 & & 44 & $13 / 87$ \\
& Supported & & & & $21 / 79$ \\
\hline
\end{tabular}

As for the variable of gender, a higher proportion of females were interested in professional development activities than males. While $35 \%$ of male teachers were found to have a low interest in professional development activities, only $27 \%$ of female teachers indicated a low interest.

The teachers were divided into two groups of less (1-5 years) and more (over 5 years) teaching experience. According to their responses, a higher percentage of less experienced teachers were interested in professional development activities as compared to the more experienced teachers. This second group also showed a high interest in such activities, and yet their percentage (84\%) was relatively lower than that of the less experienced teachers $(95 \%)$.

In addition, the respondents were categorized into three groups of 'Math' (146), 'Science' (115) as well as 'Math and Science' (39) teachers. In Chi-Square the analysis is valid only if less than $20 \%$ of the respondents with expected values are less than 5 (Bahaman \& Turiman, 1999). This means that none of the values should be below five. Therefore, the third group (Math \& Science teachers) was ignored due to the relatively low number of the teachers with low interest levels (4). In this regard, according to the descriptive statistics results, a higher percentage of Math teachers (88) were interested in professional development activities compared to the Science teachers, who indicated a lower percentage (82).

Finally, the respondents were divided into two groups of 'Supported' and 'Not supported' in terms of the administrative support that they received. The findings show that a higher percentage of the teachers who received administrative support (87) were more interested in professional development activities as compared to those who were not supported (79). 
With regard to the relationship between the independent and dependent variables of the study, the data were analyzed and the following results were obtained. Table 2 presents a summary of Chi-Square tests of the null hypotheses:

Table 2: Chi-Square Test Statistics

\begin{tabular}{lccc}
\hline & Chi-Square $\left(\mathbf{X}^{2}\right)$ & df & sig. \\
\hline Gender & 58.080 & 1 & .000 \\
Teaching experience & 152.653 & 1 & .000 \\
Major & 128.310 & 1 & .000 \\
Administrative support & 152.653 & 1 & .000 \\
\hline
\end{tabular}

As the table indicates, the Chi-Square value was significant for gender $(\mathrm{p}<.05)$. Therefore, it could be concluded that there were significant differences in the frequency of teachers' gender towards their interest in professional development activities, and the results showed that female teachers were more interested in such activities, $\mathrm{X}^{2}(1, \underline{\mathrm{N}}=300)=58.080, \mathrm{p}<.05$.

Additionally, the Chi-Square value was significant for teaching experience $(\mathrm{p}<.05)$. Therefore, it could be concluded that there were significant differences in the frequency of teachers' experience towards their interest in professional development activities, and the results showed that teachers in the less experienced group were more interested in such activities, $\mathrm{X}^{2}(1, \underline{\mathrm{N}}=300)=152.653, \mathrm{p}<.05$.

The Chi-Square value was significant for major of the teachers $(\mathrm{p}<.05)$. Therefore, it could be concluded that there were significant differences in the frequency of teachers' major towards their interest in professional development activities, and the results showed that Math teachers, as compared to Science teachers, were more interested in such activities, $\mathrm{X}^{2}(1, \underline{\mathrm{N}}=261)=128.310, \mathrm{p}<.05$.

Finally, the Chi-Square value was significant for administrative support of the teachers $(p<.05)$. Therefore, it could be concluded that there were significant differences in the frequency of the administrative support that the teachers received towards their interest in professional development activities, and the results showed that teachers who received administrative support, as compared to those who did not, were more interested in such activities, $\mathrm{X}^{2}(1, \underline{\mathrm{N}}=300)=152.653, \mathrm{p}<.05$.

\section{DISCUSSION AND CONCLUSION}

The objective of this study was to investigate the dependence of MSTs' interest in professional development activities upon their demography and administrative support. As the results indicated, the researchers failed to reject all four null hypotheses. This suggests a significant dependence of the MSTs' interest on all the independent variables of the study (gender, teaching experience, major and administrative support).

It was found that female MSTs were more interested in professional development activities. This finding was different from the results reported by Gumus, Borkowski, Deckard, and Martel (2009) that demonstrated female respondents were less likely to participate in professional development activities in contrast to males. Such a difference may originate from the respondents' various career plans and may have psychological or sociological reasons (American College of Healthcare Executives, 2008). For example, patterns of socialization formed in the individual during childhood can affect teachers' interest in social activities, including professional development programs.

As for the teaching experience, it was found that the less experienced MSTs (95\%) were more interested in professional development activities as compared to the more experienced ones (84\%). However, a large number of the more experienced MSTs were reportedly interested in professional development activities too. The findings were consistent with those of Kohl (2005), who similarly reported experienced teachers were showing interest in professional development activities. This suggests that administrators should not necessarily focus on teachers with a low teaching experience. 
Regarding the findings on the support provided for the MSTs, the findings were in line with those of Pandian and Ramiah (2004). In their study, it was found that a considerable number of the respondents (70\%) received the necessary support. Likewise, in this study, a majority of the teachers indicated they received the necessary administrative support within the ETeMS program. According to Chan \& Tan (2006), administrative support plays a vital role in teachers' interest in professional development activities. The findings of this research confirmed such a claim. The more administrative support the MSTs received, the higher interest they showed in professional development activities.

The findings of the present study can help administrators plan more appropriate in-service training programs. For instance, as it is the case in most professional development programs, the emphasis is largely on less experienced teachers. As the results of this study indicated, teachers with high experience are also interested in professional development activities. Therefore, such programs should also consider teachers with both high and low teaching experiences. In this way, administrators' better understanding of the present educational context will improve teachers' efficiency and consequently result in students' better performance.

As a final point, studies on teacher burnout indicate that teachers often feel emotionally exhausted and develop undesirable job attitudes (Maslach, Schaufell, \& Leiter, 2001). Studies on Malaysian school teachers also have shown high levels of burnout among them (Mukundan \& Khandehroo, 2010, 2009). It has, however, been suggested that professional development can attenuate burnout since it helps the teacher transcend the syndrome by increasing her personal accomplishment and self-efficacy (Mukundan \& Khandehroo, 2009). The teachers in this study were highly interested in professional development activities. Such an interest can be manipulated to overcome the deleterious effects of burnout, boosting their psychological health, which finally leads to students' better learning.

\section{AUTHOR INFORMATION}

Jayakaran Mukundan is a lecturer at the Faculty of Educational Studies, UPM, Malaysia and a visiting fellow at Leeds Metropolitan University, UK. He is also a Director on the Extensive Reading Foundation Board. His areas of interest include ESL writing and ELT textbook evaluation.

Reza Hajimohammadi holds a Master and a Bachelor degree of TEFL. Prior to pursuing his $\mathrm{PhD}$ at University Putra Malaysia (UPM) he has been a lecturer in different universities and schools of Iran since 1989. His areas of interests include language teaching methodology, writing skill, and vocabulary learning.

Vahid Nimehchisalem has been an English teacher, material developer, test developer, teacher trainer and lecturer. His areas of research interest include assessing writing, English Language Teaching (ELT) material evaluation and ELT methods. He completed his PhD in Teaching English as a Second Language (TESL) in 2010. At present, he is involved as a research assistant in several research projects in the area of ELT in Universiti Putra Malaysia (UPM).

\section{REFERENCES}

1. American College of Healthcare Executives (2008), A racial/ethnic comparison of career attainments in healthcare management. Retrieved from www.ache.org/pubs/research/research.cfm.

2. Bahaman, A. S. \& Turiman, S. (1999). Statistics for social research with computer application. Serdang: Universiti Putra Malaysia Press.

3. Grittner, F. M. \& Knop, C. K., (1975). A needs assessment of foreign language teachers today. Whitewater, WI: Wisconsin Association of Foreign Language Teachers. (ERIC Document Reproduction Service No. ED122 610)

4. Gumus, G., Borkowski, N., Deckard, G. J., \& Martel, K. J. (2009). Gender differences in professional development of healthcare managers. Leadership in Health Services 22(4). Doi: $10.1108 / 17511870910996123$

5. Hutchinson, T. and Waters, A. (1994). English for Specific Purposes. Glasgow: Cambridge University Press. 
6. Kaplan, R.B. and Baldauf, R.B. Jr. (1997). Language Planning from Practice to Theory. Clevedon: Multilingual Matters.

7. Kementerian Pendidikan Malaysia (2003). Briefing Document for the Implementation on Teaching and Learning of Science and Mathematics in English.

8. Kohl G. A. (2005). The professional development needs of K-12 ESL and foreign language teachers: A descriptive study. Unpublished doctoral dissertation, University of North Carolina (1).

9. Ladson-Billings G., \& Gomez, M, L. (2001). Just showing up: Early literacy through teachers ${ }^{5}$ professional communities. Phi delta kappan 82(9), 675-680.

10. LeLoup, J. W., \& Schmidt-Rinehart, B. C. (2003). A Venezuelan experience: Professional development for teachers, meaningful activities for students. Hispania 86(3), 586-591.

11. Lozano, L. S., Sung, H., Padilla, A. M., \& Silva, D. M. (2002). Evaluation of professional development for language teachers in California. Foreign language annals, 35(2), 161-170.

12. Maslach, C., Schaufell, W. B., \& Leiter, M. P. (2001). Job burnout. Annual Review Psychology, 52, 397422.

13. Mukundan, J. and Khandehroo, K. (2010). Burnout among English language teachers in Malaysia. Contemporary Issues in Education Research, 3(1), 71-76.

14. Mukundan, J. and Khandehroo, K. (2009). Burnout in relation to gender, educational attainment, and experience among Malaysian ELT practitioners. The Journal of Human Resource and Adult Learning, 5(2), 93-98.

15. Pelavin Associates, Inc. (1994). Developing a plan for effective ABE/ESL staff development: Implications and recommendations from the "Study of ABE/ESL instructor training approaches ". Washington, DC: Author.

16. Pandian, A. \& Ramiah, R. (2004). Mathematics and science in English: Teacher voice. The English Teacher XXXIII, 51-64.

17. Peyton, J. K. (1997). Professional development of foreign language teachers. Washington, DC: ERIC Clearinghouse on Languages and Linguistics. (ERIC Document Reproduction Service No. ED 414 768)

18. Pritchard, R. J., \& Marshall, J. C. (1994), Evaluation of a tiered model for staff development in writing. Research in the Teaching of English, 28(3\% 259-285.

19. Schmidt-Rinehart, B. O (1997). Authentic materials and Mexican immersion: A professional development program combining pedagogy, language and culture. Foreign language annals, 30(2), 201-210.

20. Terdy, D. (1993). Profiles of adult ESL teacher education programs: Flexible approaches to staff development. TESOL Quarterly 27(3), 537-541.

21. Thomson, J. (1985). Foreign language staff development needs assessment: Local/State results, 1985. Great Falls, Montana: Great Falls Public Schools. (ERIC Document Reproduction Service No. ED 274 151)

22. Yeow, P. W. (2003). How critical are critical friends? An initial study on the implementation of the buddy support system. Paper presented at the ETeMS Conference: Managing curricular change. Pearl International Hotel $2-4$ December. 


\section{NOTES}

